\title{
Monitoring of brine discharges from seawater desalination plants in the Mediterranean
}

\section{Yolanda Fernández-Torquemada* and José Luis Sánchez-Lizaso}

Unidad de Biología Marina, Dpto. de Ciencias del Mar y Biología Aplicada, Universidad de Alicante, Apdo, 99, E. 03080, Spain Fax: +34 965903815

E-mail: yolanda.fernandez@ua.es

E-mail: jl.sanchez@ua.es

*Corresponding author

\begin{abstract}
Desalination of seawater has become an important and growing industry due to the water shortage in some Mediterranean countries. This activity may result in environmental impacts, mainly generated by the discharge into the sea of the concentrate (brine) produced. Data regarding the dispersion of these hypersaline effluents, and about their effects in the marine ecosystem, are very scarce. The objective of this paper is to present some strategies for the monitoring, in time and space, of the brine discharge, and to describe the marine organisms selected as bioindicators for these studies (seagrasses and echinoderms), due to their relevance and high sensitivity to salinity changes.
\end{abstract}

Keywords: brine disposal; desalination; echinoderms; monitoring of biological communities; Posidonia oceanica.

Reference to this paper should be made as follows: Fernández-Torquemada, Y., Sánchez-Lizaso, J.L. (xxxx) 'Monitoring of brine discharges from seawater desalination plants in the Mediterranean', Int. J. Environment and Health, Vol. x, No. x, pp.xx-xx.

Biographical notes: Yolanda Fernández-Torquemada is a Graduate in Biology and in Marine Sciences at the University of Alicante, Spain. Her PhD research is focused on salinity tolerance of seagrasses and the impact of desalination. Currently, she works at the Marine Biology Unit of the Department of Marine Sciences and Applied Biology at the University of Alicante, where she collaborates in some monitoring studies of the brine discharge produced by SWRO desalination plants.

José Luis Sánchez-Lizaso is a Professor of Marine Biology and Marine Sciences in the University of Alicante, with a $\mathrm{PhD}$ on seagrass ecology. His research is focused on the management of marine living resources and the impact of human activities on marine ecosystems. Among the main topics of his research are the effects of the discharge of desalination plants and the mitigation measures that may be adopted. 


\section{Introduction}

During the last decades, water resources have been intensiveely used in some Mediterranean countries, which together with the low precipitation occurring in the zone has resulted in water scarcity (Medina San Juan, 2001). Desalination of seawater has been proposed as a possible solution for this problem, and the number of projected and constructed desalination plants has increased in this region in recent years (Medina San Juan, 2001).

Currently, the Reverse Osmosis (RO) method is the preferred desalination process mainly due to the low energy and space consumption and the reduction in the cost of the potable water obtained (Morton, Callister and Wade, 1996; Einav, Harussi and Perry, 2002; Purnama, Al-Barwani and Al-Lawatia, 2003). But this activity may cause some environmental impacts, mainly generated by the discharge into the sea of the concentrate (brine) produced (44-90 psu), and of chemicals (antiscalant, antifouling, hydrochloric acid, ferric chloride, sodium hexametaphosphate, etc.) used in desalination processes (Höpner and Windelberg, 1996; Pérez Talavera and Quesada Ruiz, 2001). When the brine is discharged into the sea, the density difference between brine and seawater will induce the formation of a stratified system, with brine forming a bottom layer that can affect the benthic communities that usually live in stable salinity environments (Del Bene, Jirka and Largier, 1994; Gacia and Ballesteros, 2001). The magnitude of this impact will depend on the characteristics of the desalination plant and its reject brine, not only the location and the area of influence of the discharge, but also on the nature and tolerance of the marine communities affected by this discharge (Ahmed et al., 2000; Einav, Harussi and Perry, 2002; Lattemann and Höpner, 2003).

Available information regarding the behaviour of these hypersaline effluents and about their effects in the marine ecosystem is limited (Pérez Talavera and Quesada Ruiz, 2001; Castriota et al., 2001; Chesher, 1975; Tomasko et al., 1999). However, the discharge of brine into the sea requires particular attention and scientific assessment of possible impacts on the marine environment. These potential impacts may be minimised by selecting an appropriate discharge location or with previous dilution of the effluent, and also by establishing a carefully designed monitoring programme in order to assess the brine plume distribution over time and taking appropriate measurements when necessary (Höpner, 1999; Einav, Harussi and Perry, 2002).

Monitoring programmes consist of the repeated observation of a system with the purpose of detecting a change (Kingsford, 1998; Short et al., 2002). These programmes should be designed to identify any potential signs of disturbance in an ecosystem at an early stage; therefore, they need a regular sampling in time with an adequate replication at more than one location. Environmental monitoring usually focuses on data collected from relevant biological or physical parameters that are considered as useful targets for assessing the studied impact, and acceptable ranges of variation for these parameters must be established.

The objective of this paper is to provide some strategies for monitoring, in time and space, a desalination plant discharge, and to describe the marine organisms selected as bioindicators for these kinds of studies (seagrasses and echinoderms), due to their relevance and high sensitivity to salinity changes. 


\section{Previous studies}

Environmental impact assessment is necessary before the desalination plant starts to operate. This process must produce a good selection of the discharge point in order to avoid sensitive communities. It is also of great relevance to carry out preliminary studies, in order to know the bathymetry and hydrodynamics of the area close to the discharge point. Data can be analysed by a computer model, like CORMIX, to predict dispersion and mixing of brine discharges in a preliminary way (Del Bene, Jirka and Largier, 1994; Doneker and Jirka, 2001). The results obtained by those models will be of great utility when planning later programmes of environmental monitoring, because it will help us to estimate the possible area affected by hypersalinity.

Nevertheless, the aim of a preliminary study is also to know the state of marine communities that could be affected by the brine in order to establish a baseline situation for key species. These key species have to be selected by their ecological relevance or their sensitivity. This baseline studies will also allow before-after comparison to detect changes on marine biota. An efficient environmental monitoring is only possible through the use of tools that allow a rapid and interpretable evaluation of the environmental conditions over time. This monitoring must involve more than just the analysis of the classical physicochemical parameters (Blandin, 1986). With this purpose, researchers propose the use of living organisms that are able to provide information about changes in the quality of existing environmental conditions (Blandin, 1986).

\section{Monitoring of the effluent dispersion (on time and space)}

It is necessary to control the temporal and spatial dispersion of the effluent by measuring the physical properties of the seawater in the vicinity of the desalination plants.

\subsection{Brine distribution in space}

It is essential to know the spatial distribution of brine in the closest area to the effluent discharge. For this reason, surveys should be carried out through the year to consider the seasonal variability (different winds, calms, breezes, etc.) and to include the possible formation of thermoclines. It is recommended to achieve at least two campaigns per year, one in summer, with calm sea conditions, which could mean a lower dilution of the brine discharge, and the other one at the end of winter, with stronger hydrodynamics conditions and a more elevated brine dilution.

In each campaign, a grid of sampling stations near the brine discharge point must be established (Figure 1). The extension of the studied area and the grid spacing will depend on the production of the desalination plant, on the type of discharge, on the receiving environment (bathymetry and hydrodynamic regimes) and on the existence of predictive models.

The samplings require Conductivity, Temperature and Depth devices (CTDs) or other equipment that can be used to obtain temperature, salinity and density profiles of the water column, with the purpose of delimiting the brine plume and its dilution throughout the area (Figure 2). 
Figure 1 Spatial representation of the salinity distribution close to a desalination effluent. Marks represent the grid of sampling stations employed

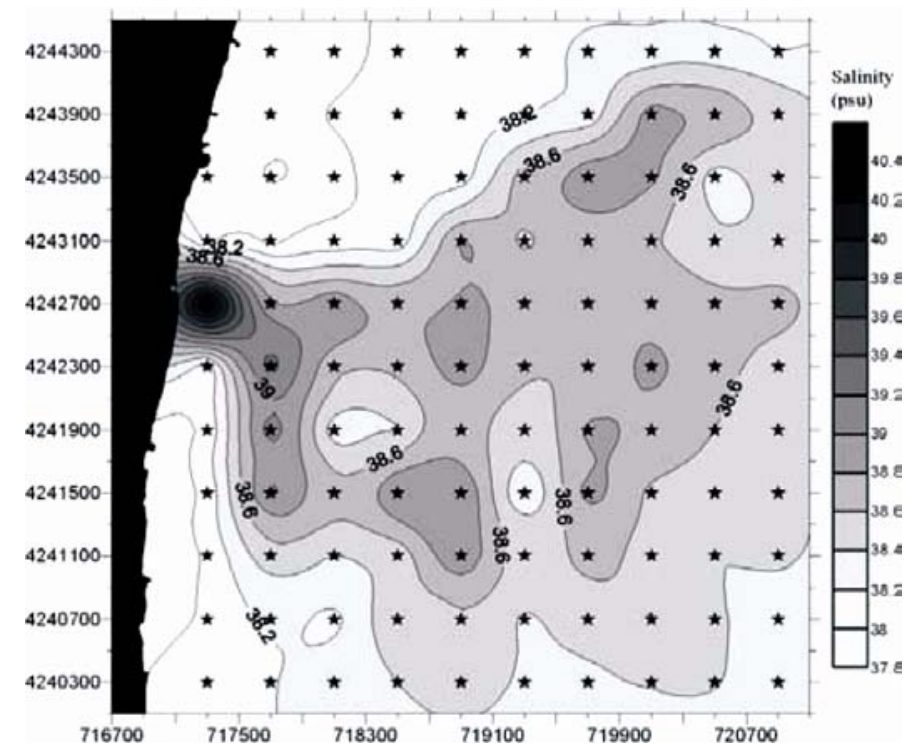

Figure 2 Example of salinity profile illustrating the vertical brine distribution in front of a desalination discharge

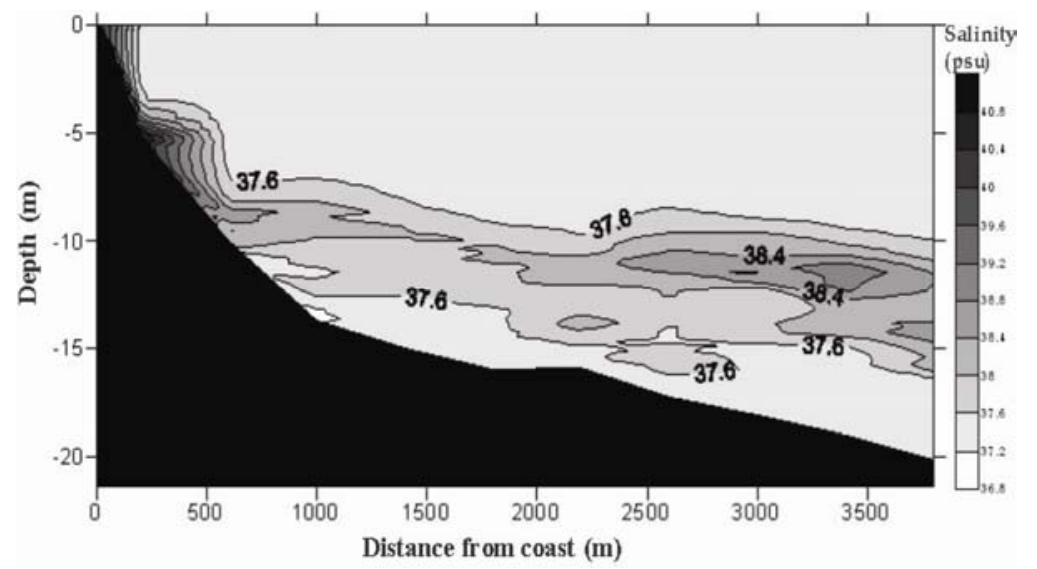

\subsection{Temporal changes of salinity}

When sensitive communities are near the discharge point, it may be interesting to have a continuous register of salinity. In addition, these measurements give us temporal fluctuations in salinity due to natural or anthropogenic causes. Conductivity and Temperature devices (CTs), with incorporated data loggers, moored near the bottom can be used for measuring simultaneously the salinity and temperature with great accuracy at multiple locations. These locations can be selected due to the presence of biological 
communities of interest, like the limit of the $P$. oceanica meadow, with the purpose of detecting if the brine affects this community, or in control localities. When the brine is diluted with seawater it may be necessary to deploy a CT before the discharge, to monitor changes in the salinity due to changes in the dilution. When previous dilution is not required, it may not be necessary for continuous salinity monitoring since the salinity of the discharge is quite constant.

\section{Monitoring effluent composition}

The main characteristic of the discharge of a RO seawater desalination plant is its high salinity. However, it may be interesting to analyse the composition of the discharge in order to detect the presence of other substances with biological relevance. In particular, the nutrient level must be controlled since it may be high if the intake is through beach wells or if compounds with phosphates are used as antiscalants. In addition, the amount of organic matter must be monitored when seawater open intakes are used. Several samples may be taken along the year but it is not necessary for a high frequency since the composition is relatively constant.

\section{Organisms selected as bioindicators}

Effective environmental monitoring programmes involve the identification of biological indicators or bioindicator species. These species must be sedentary since high mobility species do not necessary to reflect the local conditions, of ecological relevance, with a broad distribution, extensively studied and particularly sensitive to environmental variations (Molfetas and Blandin, 1981). The presence and abundance of a bioindicator can be considered as representative and integrative measures of changes on the environmental conditions. On the other hand, the combined use of different organisms and descriptors makes it possible to integrate the complexity of the ecological system and may allow a rapid detection of potential impacts. The selection of bioindicators has to be adapted to local conditions, although a wide distribution of the bioindicators is always preferable.

\subsection{Posidonia oceanica meadows}

Seagrasses represent an important ecosystem susceptible to being affected by desalination effluents, due to their location in the littoral zone and their elevated sensitivity to changes in the environmental quality (Short and Wyllie-Echeverria, 1996; Bianchi and Morri, 2000; Ferrat, Pergent-Martini and Romeó, 2003). Particularly, P. oceanica (L.) Delile is an endemic and protected seagrass of the Mediterranean Sea, where it forms one of the most relevant and productive communities (Boudouresque and Meinesz, 1982). However, this species is considered very vulnerable and has suffered a notable regression commonly attributed to several human activities (Sánchez-Lizaso, Guillen Nieto and Ramos Espla, 1990; Ruiz, 2000). Recent studies have demonstrated the low tolerance of this species to salinity increments (Buceta et al., 2003; Fernández-Torquemada and Sánchez-Lizaso, 2005). 
Consequently, given its broad distribution throughout the Mediterranean Sea and its sensitivity to augments in salinity, $P$. oceanica would be an interesting bioindicator for monitoring the brine discharges from desalination plants. Several descriptors/variables of this species can be used in the monitoring programmes. The variables most employed in other studies are density, cover, dead matte, phenology, foliar growth, shoot balance, and rhizome production (Pergent et al., 1995; Francour et al., 1999; Buia et al., 2004; Fonseca et al., 2004). Most of these data are acquired by destructive methods, collecting $P$. oceanica shoots from the studied area. However, ideally monitoring should be non-destructive to reduce interference with the system studied. Permanent parcels are non-destructive techniques that allow estimating population dynamics, shoot mortality and recruitment rate of $P$. oceanica. The size of the frame depends on the depth and the shoot density of the meadow. Fixed line transects or marks in the meadow limits can also be employed. All these microcartography techniques are very useful to detect small changes and cause minimal perturbation of the meadow.

\subsection{Echinoderms}

Echinoderms (such as Paracentrotus lividus, Echinaster sepositus, Holothuria spp, etc.) are considered as good bioindicator organisms because of their abundance and their wide distribution. They have been selected for these monitoring programmes because they are osmoconformers, which are not able to regulate their osmotic pressure. Several studies have demonstrated that they are able to tolerate only a narrow range of salinities (Irlandi, Maciá and Serafy, 1997; Basuyaux, Mathieu and Day, 1998). The decrease or total disappearance of the echinoderms in the area close to the effluent may be used as an indicator of changes in the marine communities produced by the influence of the brine from a desalination plant.

Echinoderms density may be estimated by transect lines $(10 \mathrm{~m} \times 1 \mathrm{~m})$ or using quadrates $\left(1 \mathrm{~m}^{2}\right)$. A preliminary sampling is necessary to determine the best sample unit size. In general, the lower the abundance of these species, the larger the sample unit size needs to be.

\subsection{Soft bottom fauna}

Ideally, brine discharge of desalination plants must avoid vegetated bottoms. When the discharge is produced on sandy or muddy bottoms without seagrasses and with very low density of echinoderms it may be interesting to use soft bottom infauna as a bioindicator. Samples may be obtained by dredging or diving. These samples require a long processing time and a high taxonomic competence to be identified. Effort may be reduced by focusing on some groups or identifying only down to family level. It has been observed that some families of polychaeta are quite sensitive to salinity increase. Molluscs and crustaceans may also be used since they are important components of soft bottom fauna.

\section{Experimental design}

After the selection of bioindicators, the next step is to define a correct experimental design able to deal with the natural spatial and temporal variability of these organisms and to detect effects of predetermined importance. 
An optimal sampling design should commence before the brine discharge has occurred in order to perform baseline studies, then once the desalination plant starts to operate it can be detected any change from the preliminary state. If the monitoring programme starts once the desalination discharge has occurred, asymmetrical designs should be used, and effects should be demonstrated only by comparison with controls.

By definition, monitoring studies involve repeated sampling in time. Sampling frequency will depend on the objectives of the monitoring programme, and has to consider the natural seasonal variability and the desalination production. But sampling should also be replicated in space. Monitoring programmes should produce statistically interpretable results, so sampling design must be well-planned with sufficient replicates and controls. At least three, but usually more replicates (Posidonia shoots, quadrates, transects, etc.) should be chosen in each locality. One locality must be situated as near as possible to the outlet of the desalination plant, and the other must be far enough away to be unaffected by the brine, although with similar conditions to the first one.

\section{Some examples of monitoring programmes}

Examples of some monitoring programmes of brine discharges from desalination plants carried out by the Marine Biology Unit from the Alicante University are presented in the next sections.

\subsection{Monitoring of the Seawater Reverse Osmosis (SWRO) desalination plant of Jávea (Alicante, SE Spain)}

In June 2002, a SWRO desalination plant began operation at Jávea (Alicante, SE Spain), using seawater obtained from coastal deep wells as feedwater. Currently, the plant produces $6720 \mathrm{~m}^{3}$ day $^{-1}$ of potable water per line, with a water conversion of $44.8 \%$ and a maximum production of $26,800 \mathrm{~m}^{3} \mathrm{day}^{-1}$. However, water production can vary significantly between seasons, with a significant increment during summer. Brine (68 psu) is initially mixed with seawater to get salinity lower than $44 \mathrm{psu}$, and it is emitted by 16 outfalls to increase its dilution, into an artificial channel of $700 \mathrm{~m}$ long (Fontana Channel) that discharges close to a beach. The seabed of the area next to this channel mainly consists on sand with a few patches of rocks. $P$. oceanica meadows appear at both sides of the beach at a distance of approximately $400 \mathrm{~m}$ from the channel outfall.

Monitoring was carried out from August 2002 to August 2005. During this time, a total of six campaigns were done in summer, with calm sea conditions, and in the end of winter, with stronger hydrodynamics conditions and more elevated brine dilution. In each campaign, a grid of 30 sampling stations near the brine discharge place was established. At every station, salinity measurements were taken from surface and bottom water using a CTD.

Biological organisms selected for the monitoring programme included both $P$. oceanica and echinoderms (P. lividus, Arbacia lixula and Holothuria spp), due to their high sensitiveness to changes in salinity. Three stations were selected; one close to the desalination plant discharge, and two controls (Figure 3). At each station and at three different depths $(-3,-7$ and $-15 \mathrm{~m})$, four permanent parcels were established. Each quadrate was a $40 \times 40 \mathrm{~cm}$ frame, inside of which all or at least 50 Posidonia shoots were 
marked using a cable tie. Density of echinoderms was estimated at the same localities but only at $-3 \mathrm{~m}$ depth in the $P$. oceanica meadow and over rocky substrata, with ten replicates of $1 \mathrm{~m}^{2}$ quadrates. Monitoring of these organisms was done regularly in summer of subsequent years to estimate new and dead P. oceanica shoots and changes in echinoderms density.

Figure 3 Location of the brine discharge from the Jávea desalination plant and situation of the three localities employed for the monitoring of the biological communities

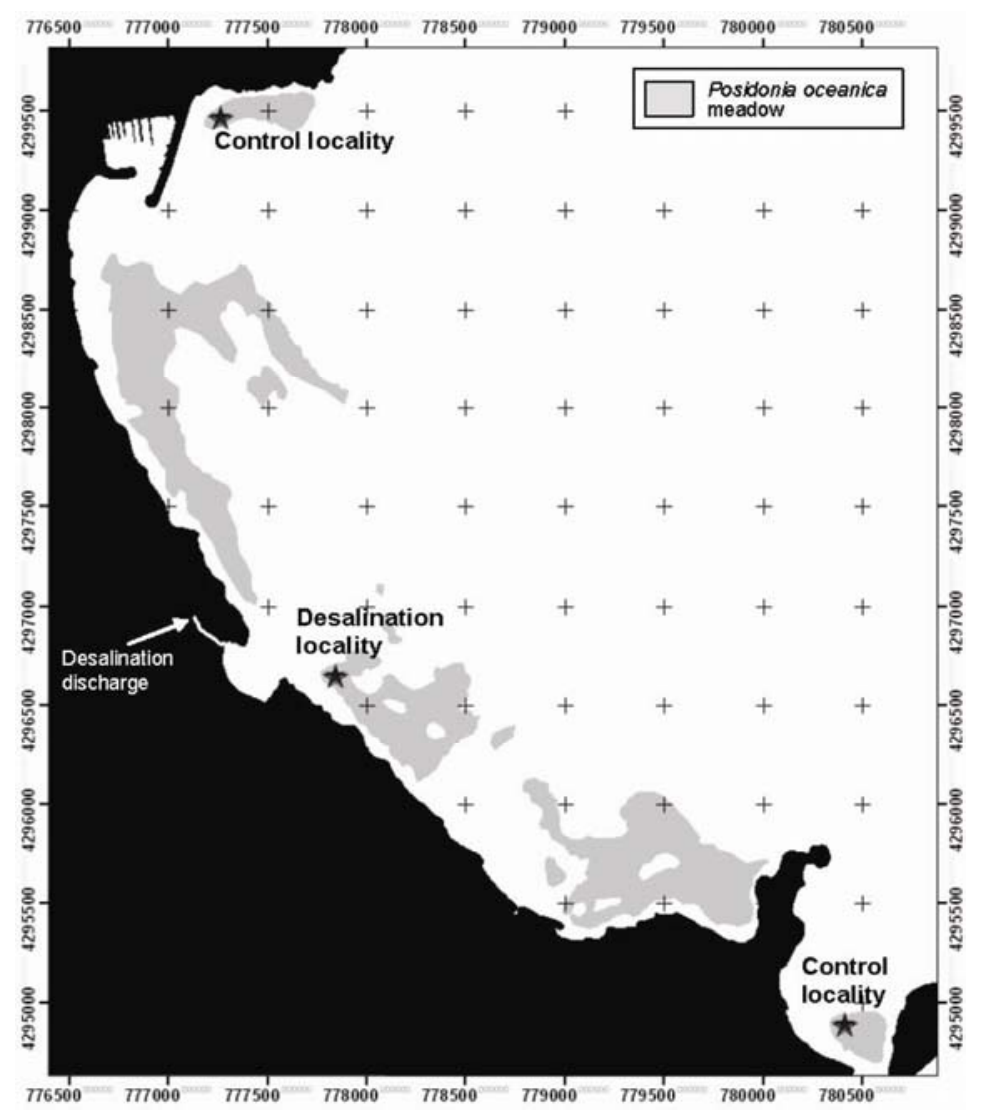

During these years, we have observed a rapid dilution of the brine discharged and no effect on the $P$. oceanica meadows and echinoderm communities of the area. The only effect observed on biological communities is the attraction of fishes near the discharge and the renewal of water from the previously anoxic channel (Fernández-Torquemada et al., 2004; Malfeito et al., 2005).

\subsection{Monitoring of the SWRO desalination plant of Alicante (SE Spain)}

A SWRO desalination plant started to work in September 2003 at Alicante (SE Spain). It has a capacity of $50,000 \mathrm{~m}^{3} \mathrm{day}^{-1}$ with a conversion factor of $40 \%$, which represents a discharge of $75,000 \mathrm{~m}^{3}$ day $^{-1}$ with a salinity of $68 \mathrm{psu}$. Discharge is produced directly on 
the coastline, on the shore south of Alicante Harbour, because this is an area degraded by previous impacts (sewages, harbour, anchoring, etc.).

From the time the SWRO desalination plant started to operate until nowadays, eight campaigns were made in February, April and August of each year. In all the surveys, a grid of more than 100 sampling stations near the brine discharge place was established. At each station, salinity, temperature and depth profiles were taken employing a CTD.

$P$. oceanica meadows that appear at $16 \mathrm{~m}$ depth and $2 \mathrm{~km}$ from the discharge point, and echinoderms were selected as bioindicators. Three stations were selected; one in front of the desalination plant discharge, and two controls, one of them, $2 \mathrm{~km}$ North and another one $2 \mathrm{~km}$ South (Figure 4). At each locality, three sites with four permanent quadrates were established in June 2003 at the upper limit of the meadow ( $-16 \mathrm{~m}$ depth) and at the continuous meadows (-20 m depth). Each permanent parcel was a $40 \times 40 \mathrm{~cm}$ frame, inside of which all Posidonia shoots were marked. Five shoots per location and depth were collected for obtaining posterior biometric data. Close to the shallow locations, CT devices were moored in order to get a continuous registration of the salinity. Density of echinoderms was estimated at the same localities but only in the upper limit of the meadow with ten replicated transects of $10 \mathrm{~m}$. Campaigns to monitor these organisms were done regularly in summer and winter of successive years to detect any changes. Soft bottom fauna has been monitored in three transects one of them in front of the discharge, at 5, 10 and $15 \mathrm{~m}$ depth. Three samples per survey and locality and two surveys per year have been done.

Figure 4 Location of the brine discharge from the Alicante desalination plant and situation of the localities employed during the monitoring programme

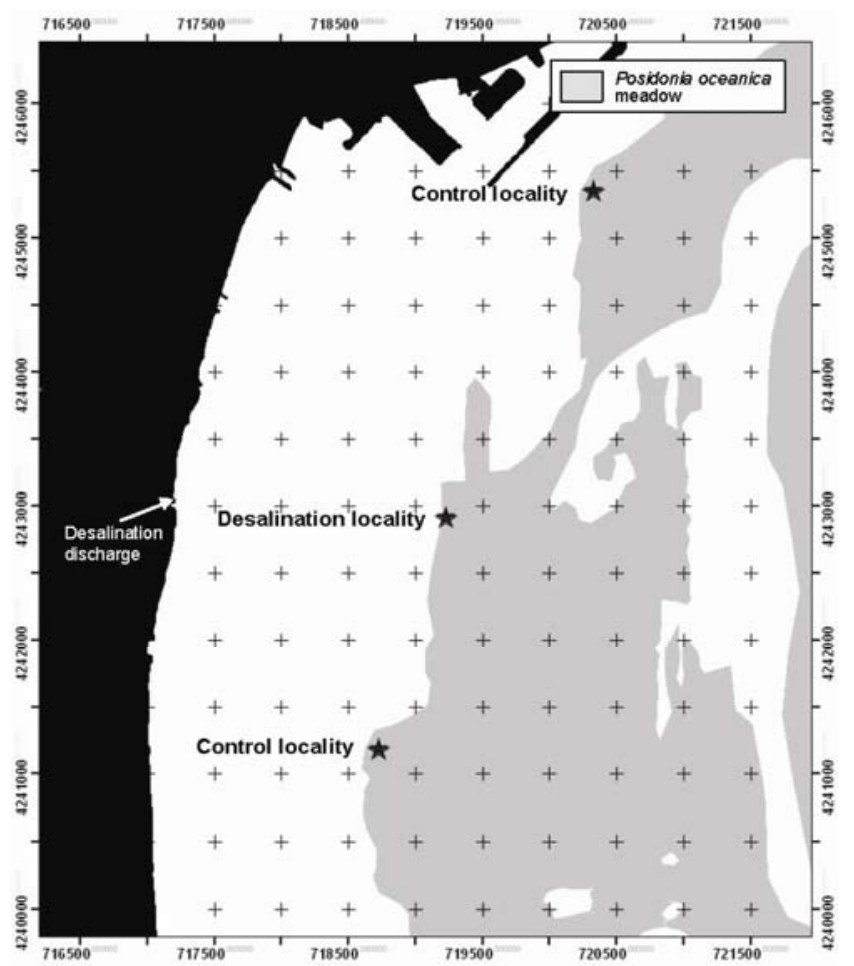


Significant increases of bottom salinity were observed several kilometres away from the discharge point, reaching the $P$. oceanica meadow, except in summer months when, due to the low temperature below the thermocline, the brine moves in the middle of the water column. A reduction of the echinoderms was observed and some changes in soft bottom fauna but no permanent damage to $P$. oceanica meadows.

\subsection{Monitoring programme of the SWRO desalination plant of San Pedro del Pinatar (Murcia, SE Spain)}

In May 2005, the SWRO desalination plant of the New Channel of Cartagena in San Pedro del Pinatar began to work. Since the construction of the main outfall for the brine discharge had not been completed, brine was provisionally discharged at the coastline, at $-2 \mathrm{~m}$ depth, after its dilution with seawater. Six CTs were deployed, one by the discharge point and five in the $P$. oceanica upper limit, two of them connected to buoys that transmit the salinity values to the plant. A protocol was established in order to increase the dilution of the brine or reduce the number of lines in operation, when salinity increments over the reference limits were observed in the meadow. During this time, a total of eight campaigns were done, coinciding with the increment of the desalination production or with new dilutions of the brine. In each campaign, a grid of 60 sampling stations near the brine discharge place was established, with the purpose of delimiting the brine plume and its dilution along the area. At each station, salinity measurements were taken from surface and bottom water.

Biological organisms selected for the monitoring programme included both, P. oceanica meadows and Dendropoma petraum formations, due to their ecological relevance, and echinoderms, due to their sensitiveness to changes in salinity. Five stations were selected: two close to the brine disposal and three controls (Figure 5). At each station, and at two different depths ( -5 and $-7 \mathrm{~m})$, three sites with four permanent parcels were established. Each quadrate (square) was a $20 \times 20 \mathrm{~cm}$ frame at $-5 \mathrm{~m}$ depth and $40 \times 40 \mathrm{~cm}$ at $-7 \mathrm{~m}$, inside of which all Posidonia shoots were counted. Ten shoots per site were collected for obtaining biometric data. Density of echinoderms was estimated at each site but only in the upper limit of the meadow $(-5 \mathrm{~m})$ with ten replicates of $10 \mathrm{~m}^{2}$, and over a substratum of dead matte and rock at $-3 \mathrm{~m}$ depth. Monitoring of biological organisms was done at each three months.

During this monitoring programme, we have detected only one episodic event of elevated salinity ( $>40 \mathrm{psu}$ ) in the upper $P$. oceanica limit, but we have not identified significant effects on the Posidonia and faunal communities. In January 2006, the construction of the main outfall was concluded, finishing the provisional monitoring programme. No evidence has been detected of environmental impacts on the organisms in the area of discharge. 
Figure 5 Location of the brine discharge from the San Pedro desalination plant and situation of the five localities employed during the monitoring programme

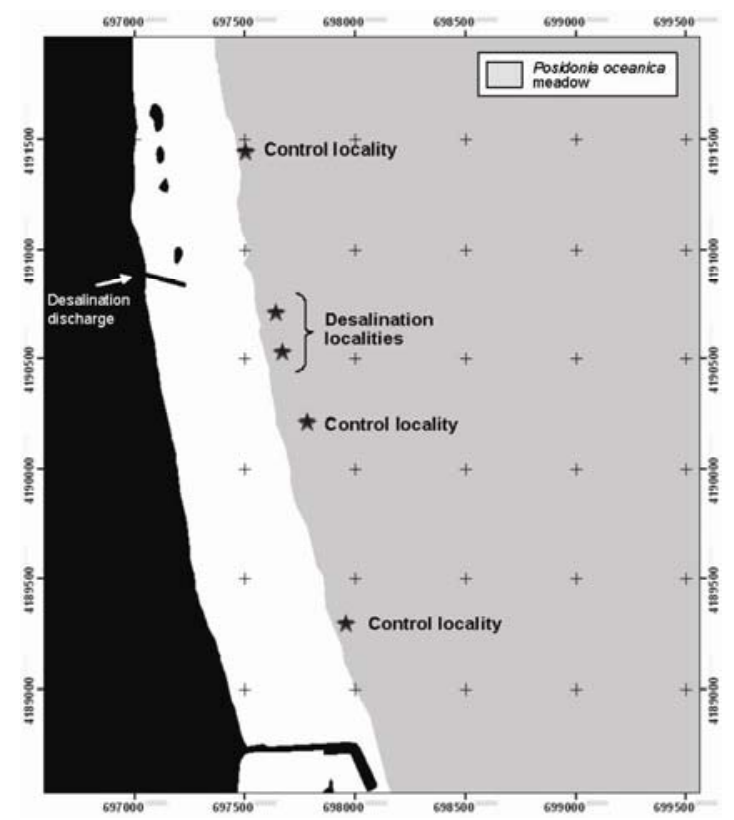

\section{Acknowledgements}

The authors would like to thank Dr. Sofia Oliveira Pires for proof-reading the English. We thank José Miguel Gonzalez Correa, Just Bayle Sempere, Marta Diaz-Valdes, Angel Loya and Yolanda Múgica who assisted in some of these monitoring programmes. We also would like to thank Marina of Alicante and Marina of Fontana Channel (Jávea) for use of equipment and facilities.

\section{References}

Ahmed, M., Shayya, W.H., Hoey, D., Mahendran, A., Morris, R. and Al-Handaly, J. (2000) 'Use of evaporation ponds for brine disposal in desalination plants', Desalination, Vol. 130, pp.155-168.

Basuyaux, O., Mathieu, M. and Day, C. (1998) 'Effets de la salinité sur la consommation alimentaire et sur la croissance de l'oursin Paracentrotus lividus et de l'ormeau Haliotis tuberculata en élevage en circuit semi-fermé', Bulletin de la Société zoologique de France, Vol. 132, pp.141-150.

Bianchi, C.N. and Morri, C. (2000) 'Marine biodiversity of the Mediterranean Sea: situation, problems and prospects for future research', Marine Pollution Bulletin, Vol. 40, pp.367-376.

Blandin, P. (1986) 'Bioindicateurs et diagnostic des systèmes écologiques', Bulletin d'Ecologie, Vol. 17, pp.211-307.

Boudouresque, C.F. and Meinesz, A. (1982) 'Decouverte de l'hervier de Posidonie', Cahier Parc Nation. Port-Cross, Vol. 4, pp.1-79. 
Buceta, J.L., Fernández-Torquemada, Y., Gacía, E., Invers, O., Mas, J., Romero, J., Ruiz, J.M., Ruiz-Mateo, A., Sabah, S. and Sánchez-Lizaso, J.L. (2003) 'Investigación conjunta sobre la tolerancia de Posidonia oceanica a incrementos de salinidad', Ingeniería Civil, Vol. 132, pp.111-116.

Buia, M.C., Gambi, M.C. and Dappiano, M. (2004) 'Seagrass system', Biologia Marina Mediterranea, Vol. 10, pp.133-183.

Castriota, L., Beltrano, Ç.M., Giambalvo, O., Vivona, P. and Sunseri, G. (2001) 'A one-year study of the effects of a hyperhaline discharge from a desalination plant on the zoobenthic communities in the Ustica Island Marine Reserve (Southern Tyrrhenian Sea)'. In: 36 CIESM, Monaco.

Chesher, R.H. (1975) 'Biological impact of a large-scale desalination plant at Key West, Florida', in E.J. Ferguson and R.E. Johanes (Eds),Tropical marine pollution (pp.81-99). Amsterdam: Elsevier Scientific Publishing Company.

Del Bene, J.V., Jirka, G. and Largier, J. (1994) 'Ocean brine disposal', Desalination, Vol. 97, pp.365-372.

Doneker, R.L. and Jirka, G.H. (2001) 'CORMIX-GI systems for mixing zone analysis of brine wastewater disposal', Desalination, Vol. 139, pp.263-274

Einav, R., Harussi, K. and Perry, D. (2002) 'The footprint of the desalination processes on the environment', Desalination, Vol. 152, pp.141-154.

Fernández-Torquemada, Y. and Sánchez-Lizaso, J.L. (2005) 'Effects of salinity on leaf growth and survival of the Mediterranean seagrass Posidonia oceanica (L.) Delile', Journal of Experimental Marine Biology and Ecology, Vol. 320, pp.57-63.

Fernández-Torquemada, Y., González Correa J.M., Carratalá Giménez, A. and Sánchez Lizaso, J.L. (2004) 'Medidas de atenuación del posible impacto ambiental del vertido de las desaladoras de osmosis inversa: El ejemplo de Jávea (Alicante)', in IV Congreso Ibérico sobre Gestión y Planificación del Agua. Tortosa, p.9.

Ferrat, L., Pergent-Martini, C. and Romeó, M. (2003) 'Assessment of the use of biomarkers in aquatic plants for the evaluation of environmental quality: application to seagrasses', Aquatic Toxicology, Vol. 65, pp.187-204.

Fonseca, M.S., Whitfield, P.E., Kenworthy, W.J., Colby, D.R. and Julius, B.E. (2004) 'Use of two spatially explicit models to determine the effect of injury geometry on natural resource recovery', Aquatic Conservation: Marine and Freshwater Ecosystems, Vol. 14, pp.281-298.

Francour, P., Ganteaume, A. and Poulain, M. (1999) 'Effects of boat anchoring in Posidonia oceanica seagrass beds in the Port-Cros National Park (north-western Mediterranean Sea)', Aquatic Conservation: Marine and Freshwater Ecosystems, Vol. 9, pp.391-400.

Gacia, E. and Ballesteros, E. (2001) 'El impacto de las plantas desalinizadoras sobre el medio marino: la salmuera en las comunidades bentónicas mediterráneas', in Conferencia Internacional: El Plan Hidrológico Nacional y la Gestión Sostenible del Agua. Aspectos Medioambientales, Reutilización y Desalación. Zaragoza, p.10.

Höpner, T. (1999) 'A procedure for environmental impact assessments (EIA) for seawater desalination plants', Desalination, Vol. 124, pp.1-12.

Höpner, T. and Windelberg, J. (1996) 'Elements of environmental impact studies on coastal desalination plants', Desalination, Vol. 108, pp.11-18.

Irlandi, E., Maciá, S. and Serafy, J. (1997) 'Salinity reduction from freshwater canal discharge: effects on mortality and feeding of an urchin (Lytechinus variegatus) and a gastropod (Lithopoma tectum)', Bulletin of Marine Science, Vol. 61, pp.869-879.

Kingsford, M. (1998) Studying Temperate Marine Environments: a Handbook for Ecologists. Christchurch: Canterbury University Press (p.335).

Lattemann, S. and Höpner, T. (2003) Seawater Desalination. Impacts of Brine and Chemical Discharges on the Marine Environment. L'Aquila, Italy: Desalination Publications (p.142). 
Malfeito, J.J., Díaz-Caneja, J., Fariñas, M., Fernández-Torquemada, Y., González-Correa, J.M., Carratalá-Gímenez, A. and Sánchez-Lizaso, J.L. (2005) 'Brine discharge from the Jávea desalination plant', Desalination, Vol. 185, pp.87-94.

Medina San Juan, J.A. (2001) 'La desalación en España. Situación actual y previsiones', in Conferencia Internacional: El Plan Hidrológico Nacional y la Gestión Sostenible del Agua. Aspectos medioambientales, reutilización y desalación. Zaragoza (p.7).

Molfetas, S. and Blandin, P. (1981) 'Quelques éléments de réflexion sur la notion d'indicateur écologique', in Ecologie appliquée-Indicateurs biologiques et techniques d'études (pp. 167-173). Journées d'étude de l'association française des ingénieurs écologues. Grenoble: Afic. publ.

Morton, A.J., Callister, I.K. and Wade, N.M. (1996) 'Environmental impacts of seawater distillation and reverse osmosis processes', Desalination, Vol. 108, pp.1-10.

Pérez Talavera, J.L. and Quesada Ruiz, J.J. (2001) 'Identification of the mixing processes in brine discharges carried out in Barranco del Toro Beach, south of Gran Canaria (Canary Islands)', Desalination, Vol. 139, pp.277-286.

Pergent-Martini, C., Leoni, V., Pasqualini, V., Ardizzone, G.D., Balestri, E., Bedini, R., Belluscio, A., Belsher, T., Borg, J., Boudouresque, C.F., Boumaza, S., Bouquegneau, J.M., Buia, M.C., Calvo, S., Cebrian, J., Charbonnel, E., Cinelli, F., Cossu, A., Di Maida, G., Dural, B., Francour, P., Gobert, S., Lepoint, G., Meinesz, A., Molenaar, H., Mansour, H.M., Panayotidis, P., Peirano, A., Pergent, G., Piazzi, L., Pirrotta, M., Relini, G., Romero, J., Sanchez-Lizaso, J.L., Semroud, R., Shembri, P., Shili, A., Tomasello, A. and Velimirov, B. (2005) 'Descriptors of Posidonia oceanica meadows: use and application', Ecological Indicators, Vol. 5, pp.213-230.

Purnama, A., Al-Barwani, H.H. and Al-Lawatia, M. (2003) 'Modelling dispersion of brine waste discharges from a coastal desalination plant', Desalination, Vol. 155, pp.41-47.

Ruiz, J.M. (2000) Respuesta de la fanerógama marina Posidonia oceanica (L.) Delile a perturbaciones antrópicas. PhD Thesis. Universidad de Murcia, Spain (p.212).

Sánchez-Lizaso, J.L., Guillen Nieto, J.E. and Ramos Espla, A.A. (1990) 'The regression of Posidonia oceanica meadow in El Campello Spain', Rapport Committee International de la Mer Mediterranee, Vol. 32, p.10.

Short, F.T. and Wyllie-Echeverria, S. (1996) 'Natural and human-induced disturbances of seagrasses', Environmental Conservation, Vol. 32, pp.17-27.

Short, F.T., McKenzie, L.J., Coles, R.G. and Vidler, K.P. (2002) SeagrassNet manual for Scientific Monitoring of Seagrass Habitat (QDPI, QFS, Cairns), p.56.

Tomasko, D. A., Blake, N. J., Dye, C. W. and Hammond, M. A. (1999) 'Effects of the disposal of reverse osmosis seawater desalination discharges on a seagrass meadow (Thalassia testudinum) offshore of Antigua, West Indies', in S.A. Bortone (Ed.), Seagrasses: Monitoring, Ecology, Physiology and Management (pp.99-112). Boca Raton, Florida, EE UU: CRC Press. 